DOI: 10.15587/2312-8372.2018.129877

\title{
Grygorak M. \\ FORMATION OF MANAGEMENT MECHANISMS OF BALANCED DEVELOPMENT OF LOGISTICS SERVICES MARKET
}

Об'єктом дослідження є соціально-економічні відносини між органами державної влади, суб'єктами ринку логістичних послуг та саморегулівними організаціями. Одним з найбільш проблемних місць є пошук оптимального поєднання форм і методів державного регулювання розвитку ринку логістичних послуг та саморегулювання. Реалізація логістичної стратегї має створити принципово нові можливості для виявлення конкурентоспроможних українських виробництв $і$ їх включення в міжнародний поділ праці. Вона також має створити інформаційну базу для проведення дослідження украйнського ринку та його бенчмаркінгу за міжнародними стандартами статистичної звітності.

В ході дослідження обгрунтовано теоретичний базис, форми і методи державного регулювання розвитку логістичної сфери в Україні. Виокремлено три складові: механізм державного регулювання логістичної діяльності на макрорівні, механізм саморегулювання ринку, що визначає діяльність постачальників логістичних послуг на мікрорівні. А також механізм взаємодї, гармонізацї інтересів та соціального партнерства, що реалізує управління логістичними потоками на мезорівні шляхом створення нових інтеграційних форм та логістичних утворень за регіональними або галузевими ознаками. Акцентовано увагу на тому, що держава повинна стимулювати, з одного боку, ефективність та інноваційність суб'єктів ринку логістичних послуг, а з іншого - жорстко контролювати дотримання нормативно-правових актів і стандартів якості логістичного сервісу та екологічних вимог. Державне управління логістичними потоковими процесами в ланиюгах/мережах постачання, кластерах та інших організаційних формах сприятиме зменшенню сукупної доданої вартості в структурі національного валового продукту та сприятиме підвищенню ефективності i конкурентоспроможності національної економіки. Визначено перспективні напрями та форми саморегулювання ринку логістичних послуг в контексті державних пріоритетів. Доведено зростаючу роль саморегулівних організащій (асоціацій, професійних об’єднань, союзів) у формуванні професійних стандартів, кодексів чесної конкурениї, підвищення рівня компетентності суб'єктів логістичної діяльності. Зроблено висновок про необхідність розвитку гібридних форм і впровадження принципів державно-приватного партнерства. Розроблено систему логістичного контролінгу для своєчасного коригування стратегічних цілей і внесення змін щодо розвитку ринку логістичних послуг. Розроблено конщептуальну модель контролінгу ринку логістичних послуг, яка включає модулі державного контролінгу та самоконтролінгу суб'єктів ринку. Запропоновано систему збалансованих показників ефективності логістичної діяльності, яка дозволить забезпечити збирання та оброблення статистичних даних.

Ключові слова: національна логістична система, державне регулювання логістичної діяльності, ринок логістичних послуг, саморегулювання ринку, логістичний контролінг.

\section{Introduction}

The diversity of the strategic development of the logistics system in Ukraine necessitates the search for mechanisms for the optimal combination and harmonization of economic, social, institutional interests. In this case, the role of the state as a regulator of socio-economic relations between providers of logistics services and their consumers is growing. Now the implementation of logistics activities takes place in conditions of objective weakness of the state when the activities of the subjects of the logistics services market are of little use. However, the formation of the national economic interest occurs on the basis of awareness of integral needs by the socio-economic institutions and market players of logistics services, they are united. Only if the combination of the thoughts of the public sector, business and the public it is possible to success- fully implement the national logistics strategy. Therefore, it is relevant to study the economic essence and forms of implementation of modern management technologies and mechanisms of impact to ensure a balanced development of the logistics services market in Ukraine.

\section{The object of research and its technological audit}

The object of research is the socio-economic relations between government bodies, the subjects of the market of logistics services by self-regulating organizations. The implementation of the Association Agreement with the EU provides for regulatory harmonization of EU legislative development under the national legislation of Ukraine [1]. Harmonization and implementation of regulatory and legal acts in the field of logistics and transport should contribute 
to the introduction of the best world practices in managing goods movement in supply chains. It also stimulates the development of transport corridors, multimodal and container transportation, the creation of a network of logistics centers, the cooperation of market players in logistics services and the increase of their competence. The experience of the most efficient countries from the point of view of logistics, in particular Germany, France, the Netherlands [2,3], testifies that the pledge of their success was the national logistic strategy (national logistic strategy). It determines the strategic vision of the country's development and resources to achieve this vision. The EU experts determined global trends in the development of logistics and their impact on the effectiveness of national economies of the European community [4]. The conducted researches testify to the growing role of the institutional provision of logistics activities and the need to further improve the forms and methods of managerial influences on the activities of logistics companies.

One of the most problematic areas is the search for the optimal combination of forms and methods of state regulation of the development of the market of logistics services for self-regulation. The implementation of the logistics strategy should create fundamentally new opportunities for identifying competitive Ukrainian productions and their inclusion in the international division of labor. It also creates an information base for conducting research on the Ukrainian market and its benchmarking in accordance with international statistical reporting standards.

\section{The aim and objectives of research}

The aim of research is justification of the structure of state regulation mechanisms and self-regulation of the balanced development of the logistics services market. To achieve this aim, the following tasks are defined:

1. To substantiate the forms and methods of state regulation of the development of the logistics sector.

2. To define perspective directions and forms of selfregulation of the market of logistical services in the context of state priorities.

3. To develop a system of logistic controlling for the timely correction of strategic goals and making changes regarding the development of the market.

\section{Research of existing solutions of the problem}

Let's note that among scientists there is no single point of view on the problem of the formation of effective management technologies on the influence of the state and state institutions on the development of market relations. Supporters of the market theory of free competition believe that economic processes are regulated by market mechanisms and deny the advisability of influencing them by external regulation, that is, the state. Other scientific schools, on the contrary, prove the need for state intervention, explaining this by the need to prevent crisis phenomena and reduce social risks [5-7]. However, the existing competition in the logistics services market requires new approaches to the development of socio-economic relations between logistics service providers and their consumers. The lack of centralized management does not contribute to the balanced development of all subsystems of national and regional logistics systems. It hampers the widespread use of modern concepts of chain/supply chain management for goods and services. The mechanism of market self-regulation does not allow to fully optimize its development and ensure the maximum effect of logistics activities. It can't overcome the negative tendencies connected with the monopolistic activity of individual participants and the active influence of other factors of the external environment.

The growth of the role of institutional support for the activities of market actors in general, and logistic particular, many researchers write. The most successful system of tools and instruments of state regulation is described in $[8,9]$. The development of the national transport network in the context of European integration is investigated in $[10,11]$. The author [12] draws attention to the need to define the concept of a strategy for state regulation of the industrial-logistical system. In scientific publications [13, 14], a comparative analysis of instruments of public-private partnership in Ukraine and abroad is made. The generalization of international experience testifies to the existence of effective mechanisms for self-regulation of market relations and the possibilities to increase the efficiency of logistic activity due to their optimal combination [15-19]. Controlling is one of the modern management tools [20, 21]. The possibility of using controlling in the public administration and in logistics is investigated [22, 23]. However, the formation of a system of mechanisms for managing the balanced development of the logistics services market requires a more in-depth study.

However, the formation of the logistics system in Ukraine and the definition of the direction of its development require constant and more in-depth research.

\section{Methods of research}

To solve the tasks set, the following methods are used: system analysis and aggregation, logical generalization and comparative comparison, system decomposition, general theory of logistics and public administration theory, modern concepts of regulation of social-market relations. To determine the starting points of the study, the works $[6,8,9]$ are used, in which the forms and methods of state regulation of market relations are proposed. Scientific provisions [15-18] define a set of methods and tools for self-regulation in logistics and supply chains. On the basis of scientific developments [20-24], a set of mechanisms of state controlling and self-control of the market of logistics services is formed. Also, conceptual modules for the collection and processing of statistical and management information for adjusting strategic goals are identified.

\section{Research results}

The generalization of theoretical studies on the management of market relations made it possible to formulate the following hypothesis: an optimal combination of institutional regulatory systems with market mechanisms of self-regulation is the key to the high efficiency and flexibility of managing logistical flow processes in the spacetime dimension both at the national economy level and at the level of its structures.

To prove this hypothesis, it is necessary to use an integrated and systematic approach that determines management impacts in the context of three key interrelated areas: 
- at macroeconomic state regulation ensures the creation and maintenance of favorable conditions for the dynamic development of the market of logistics services, and also determines the priority directions of this development with the formation of key tasks, development indicators and organizational and economic instruments for their support;

- at the microeconomic level - this is an internal corporate management of the activities of logistics service providers, ensures their competitiveness in the market is increased by increasing the level of competence, the degree of innovation activity and the quality of logistics services for consumers;

- at the mesoeconomic level, an integral unity of the regional (spatial) and branch (functional) aspects of the functioning of the national economic system is formed. This is similar to the horizontal and vertical dimensions of the national economy. This approach ensures synergy of interaction and business partnerships through vertical and horizontal integration, taking into account the effectiveness criteria and the use of mechanisms to harmonize economic interests.

The environment in which logistical flow processes are carried out, including socio-economic conditions and a set of resources that ensures the coherence of these conditions and the spatial movement of logistical flows. The effectiveness of joint actions is expressed by the synergetic effect of complex behavior of logistics systems, and decision-making almost always has a nonlinear character. One of the main properties of the logistics system is the ability to internal transitions, changes, provides system stability and the ability to adapt to changes in both external conditions and internal state. Systemic homeostasis supports the basic parameters of the system and is aimed at preserving its prescribed state, in which the system is stable. The stand homeostatic system consists of opposites united in a certain way, which balance with each other and compensate each other. When their equilibrium is violated, special means are needed to maintain stability, special management methods. Thus, a systematic approach to managing the development of the market of logistics services involves the specification of subjects and management objects that interact with the use of direct and reverse information links (Fig. 1).

The object of organized regulation in logistics is a set of material, financial and information, streaming processes, including export-import. The function of the logistic tool is the combination of organizational, technological, economic, environmental and other opportunities and interests of all subjects of the process of commodity circulation, from the perspective of its perception as a system. The decisionmaking subsystem should ensure the unity of the goals and methods of achieving them, and also allow monitoring of the degree of achievement of the set goals and objectives.

Management of logistics processes at all levels of management with different subject-object structure and tool base provides for economic and legal support, is determined by the national market environment of logistics activities and the global logistics environment. Planning, organization, implementation and monitoring of logistics processes are a complex and extensive set of procedures based on legal, administrative, economic and commercial principles. The more heterogeneous elements of the system and its complex connections, the greater the probability of a violation of the stability of its functioning. This pattern is described by Legasov's law - the higher the level of the system, the more unstable it is and requires more resources to maintain its functioning.

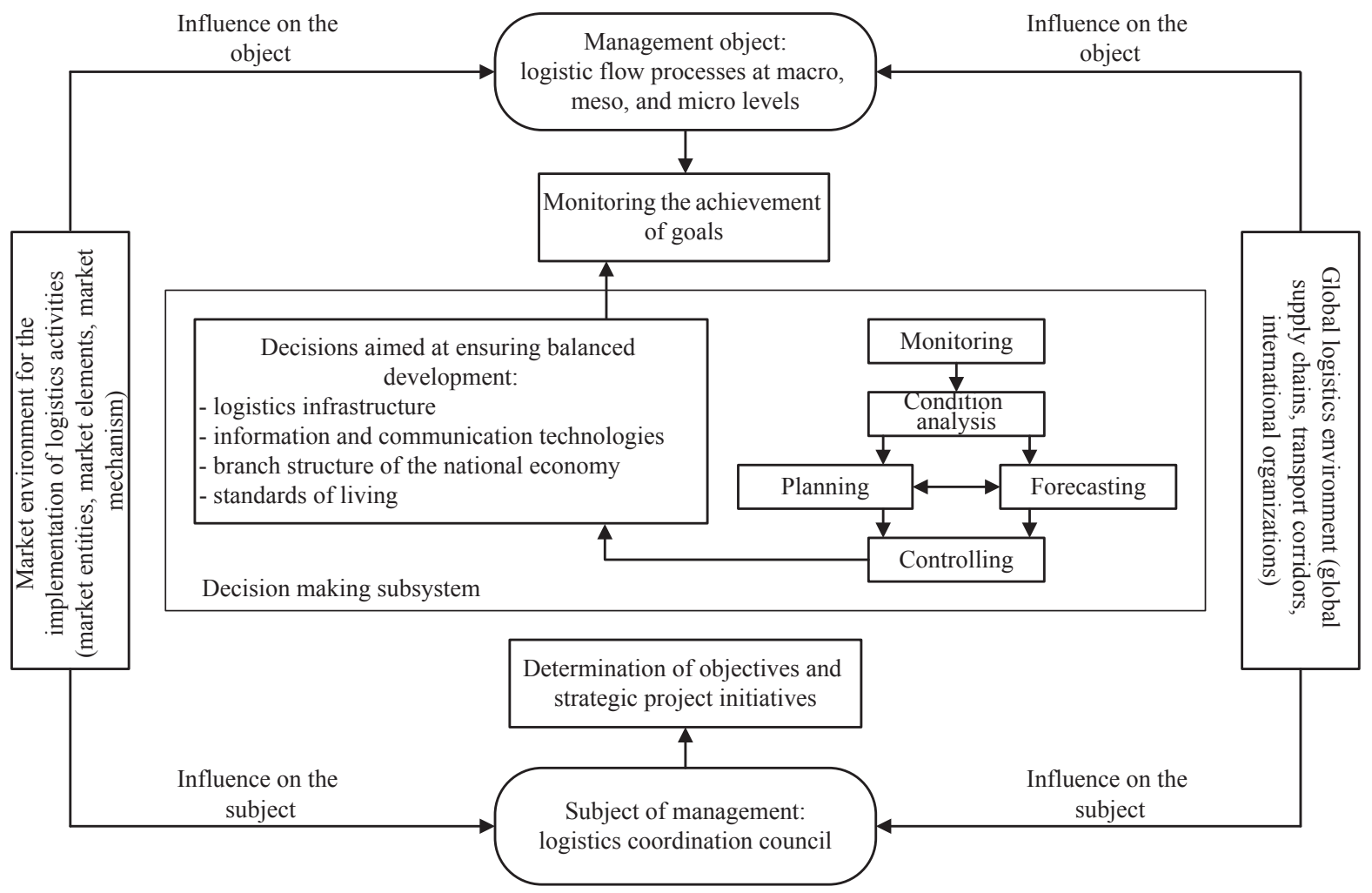

Fig. 1. A systematic approach to managing the development of the logistics services market (generalized by the author on the basis of [6, 9, 20, 21]) 
But the more unstable the system, the more ways of development it can choose at the bifurcation point, and two close states can give rise to different trajectories of system development.

Let's note that the mechanism for managing the development of the market of logistics services is considered a set of organizational and economic methods, tools, technologies and instruments of the impact of the subjects of management on the state and structure of the national logistics system. The purpose of this influence is ensuring the correspondence between the target quantitative and qualitative indicators and the actual state of its components, including the logistics services market. The use of the term «mechanism» in the study of the logistics services market is not accidental, since it fully expresses the concept of integrity, the meaning of each element, the structure, the possibilities of interaction and interrelations, the violation of which leads to a change in the stability of the entire system and its components. It shows the dynamics, means and nature of the transition from one state of the system to another. The structure of an integrated mechanism for managing a balanced development of the logistics business is shown in Fig. 2.

The basis for the functioning of the complex mechanism of LSM balanced development is the principles reflecting the criteria for the quality of logistics services. They are also connected with the directions of sustainable development of the national logistics system. Implementation of certain principles is ensured by combining the market mechanism of self-regulation of logistics processes and the system of measures of state regulation of logistics activities at all levels of the national economy. The following components are distinguished:

1) the mechanism of state regulation of logistics activities at the macro level;

2) mechanism of market self-regulation that determines the activities of logistics service providers at the micro level;

3 ) the mechanism of interaction, harmonization of interests and social partnership, realizes the management of logistical flows at the meso level by creating new integration forms and logistic entities on regional or sectoral grounds. Let's consider these components in more detail.

The mechanism of state regulation of logistic activity determines the rules of behavior of all subjects of the market of logistics services. Strategic objectives and guidelines are defined by the national logistics strategy. State institutions should effectively interact with public professional organizations and private businesses. It should be noted that supporting the implementation of the logistics strategy should stimulate the development of the logistics business, help to improve the quality and competitiveness of logistics services in Ukraine and international markets.

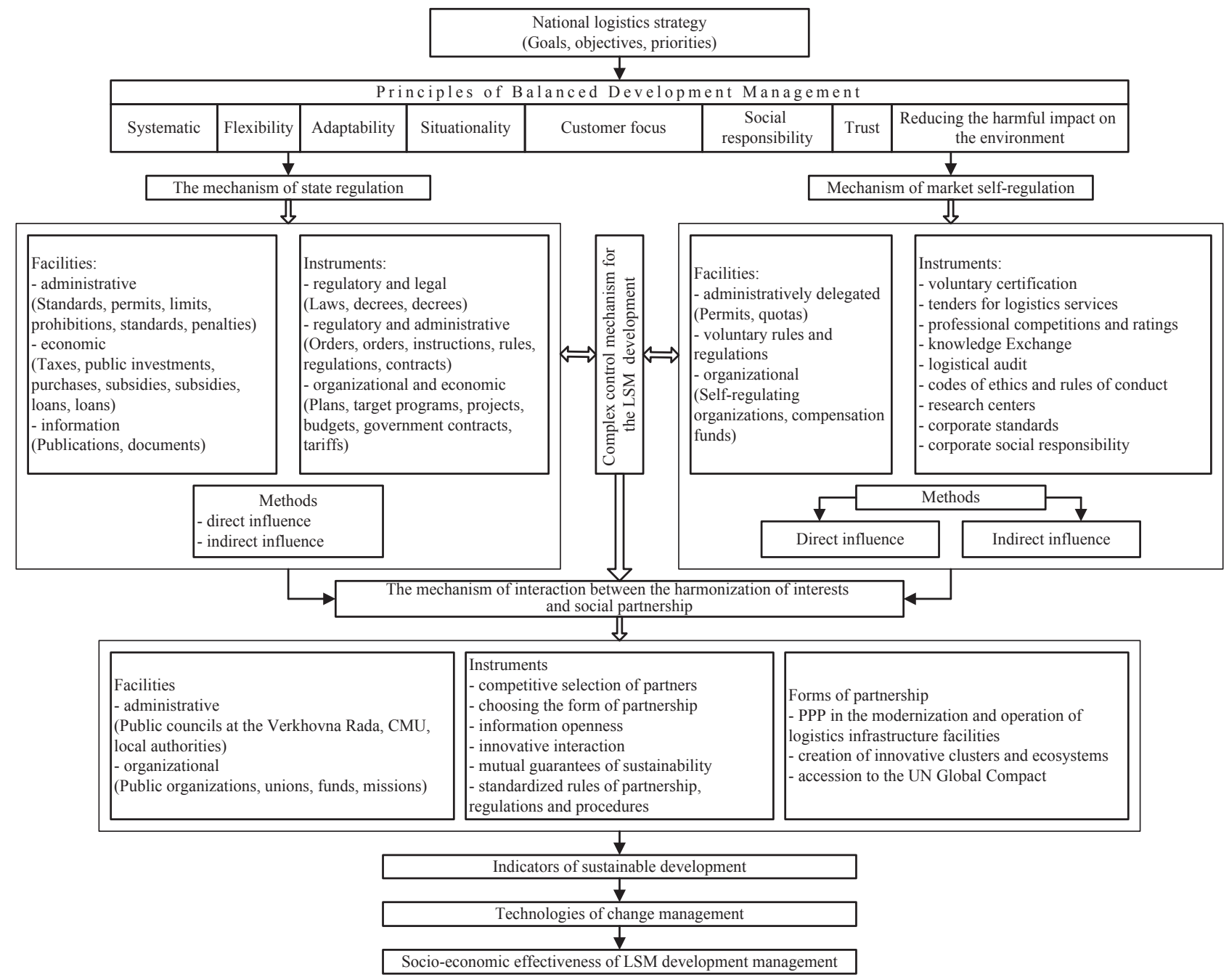

Fig. 2. The structural scheme of an integrated mechanism for managing the balanced development of the logistics services market 
In turn, the means and instruments of state regulation are realized through the methods of state management, that is, the methods of state-administrative influence, among which in the overwhelming majority of scientific research determine:

- classically direct methods of state regulation (legis-

lative regulation, stimulation of the creation of new enterprises, etc.);

- indirect (state financial policy, monetary, fiscal).

In general, the mechanism of combining methods of direct and indirect regulation, legal, administrative and economic methods may vary depending on the development of market relations in the country, the financial and economic situation of the national economy. With the development of market relations, involvement in the regulation of institutions, the methods of the market of direct influence (administrative) tend to give way to indirect (economic) and play a secondary role. Their use becomes useful when the market mechanism and economic means of state regulation of the economy are insufficient or too slow.

The organization of processes in logistics systems should be based on the following principles of state regulation: - compliance with existing legal norms that promote the protection of the interests of logistics service providers and their counterparties and third parties;

- optimal redistribution of the synergetic effect as a result of better use of logistics capacities and efficient management of supply chains/networks of goods and services;

- clear and effective regulatory support for each level of logistics activities, has the best compatibility with the micro-systems of other organizational units (enterprises, government agencies and institutions, individuals, etc.).

Self-regulation is the opposite of vertical (state) regulation, which provides hierarchy and subordination. Although in practice, self-regulation and state regulation do not exclude, but rather complement each other, forming an effective, complete system of control over the activities of market entities. Effective self-regulation presupposes the availability of: a professional code (standards of doing business) developed by market participants independently; mechanisms for enforcing such codes and monitoring participants, sanctions for violation of the rules; effective dispute resolution system. The peculiarity of the Ukrainian economy is determined by the fact that Ukraine adapts to the conditions of the market in a peculiar way, it is on the way to building a civilized and democratic society. The evolution of the development of institutional formations and their transformation into professional associations is a clear example of the gradual transition of the Ukrainian economy from rigidly administrative management through self-supporting relationships, to the creation of conditions for professional self-regulation of professions, industries and spheres of activity [15, 17]. Unlike Ukraine, in most European countries with a high level of development in terms of the index of logistic efficiency of the economy (Germany, Holland, Great Britain, Italy), self-regulatory organizations (SROs) function effectively. Logistic associations, unions and other associations play a key role in regulating professional activity, creating standards for the activities of logistic service providers of the professional competencies of logistics personnel.

The third component of the integrated mechanism for managing the LSM balanced development is the mecha- nism of interaction, harmonization of interests and social partnership. Let's note that in some scientific works the terms «mixed regulation», «contractual regulation», «quasiregulation» or «co-regulation» are used [15]. Co-regulation elements are formed by introducing representatives of business and the public in the management structure of public authorities. Therefore, the same self-regulating organizations can be participants in co-regulation. Co-regulation and self-regulation is at the same time more flexible types of regulation of logistics activities in comparison with state regulation, after all, the participants of the commodity movement and consumers of goods and services activate and directly join the process. The new methodological approach builds up the system of relations between the state and business, can give a powerful impetus to the development of the market of logistics services with the participation of public organizations and associations of entrepreneurs and international organizations. Financial and investment mechanisms for the implementation of transport and logistics infrastructure projects should provide for the allocation of funds for state support of socially significant facilities and attraction of private sector resources and international investment funds in accordance with an adequate and transparent development plan for the industry with a clear definition of the most priority projects.

Based on the generalization of scientific works of scientists, let's clarify the basic theoretical provisions that create the prerequisites for using methods and tools of controlling to manage the development of the logistics services market.

1. Controlling is a mechanism for coordinating and ensuring the interconnections and interdependence of information flows between all subjects of the logistics services market, as well as between the levels and subsystems of the national logistics system. The application of controlling is carried out with the purpose of adaptation to the changing conditions of the external environment and is oriented to a long-term perspective due to the coordination of the current plans of logistics activities of market entities with the National Logistics Strategy.

2. From the point of view of the process approach, controlling represents a system for regulating and monitoring the implementation of logistics business processes at various levels of the national economy, selecting criteria for key performance indicators of the processes, assessing the effectiveness of their implementation with a view to further improving the strategic objectives of logistics activities.

3. Controlling de facto completes the management cycle, forms the basis (potential) of the future effectiveness of the subjects of logistics activities and determines the system of indicators of information support and the collection of statistical information for measuring strategic objectives and assessing their reach.

4. Strategic controlling involves:

- analysis of the external and internal environment of logistics activities, competition and significant factors of market success;

- strategic plans and monitored performance indicators; - strategic positioning of logistics service providers; - cost-forming factors and portfolio of innovative development strategies and business models of the activities of the subjects of logistics activities. 
5. The modern concept of controlling focuses on optimizing the interests of stakeholders (state, business, social institutions, population), which corresponds to the priorities of innovative development of the national logistics system and implements the principles of decentralization, selforganization, self-control and self-management at all levels of logistic activity. Accordingly, it is necessary to build a harmonious system of regulation and management of logistical flows and processes, at which at the microeconomic level the sustainability of the system will be provided by self-regulating organizations, and at the macroeconomic level - the system of state regulation and administration of the national logistics system that implements logistics concepts and the national logistics strategy.

The theoretical assumptions made allow to propose a conceptual model of controlling the logistics services market. It is the theoretical basis for constructing organizational structures of controlling subdivisions in the system of state management (state controlling) and logistics companies (self-control). The methodological basis of controlling functions at different levels of the hierarchy of management of logistical flow processes is the formalization of its procedures and the choice of methods. The purpose of the integration and communication mechanism is coordination, coordination and harmonization of the interests of the subjects of the logistics services market taking into account the strategic priorities of the development of the national logistics system (Fig. 3).

Let's define the main goal of controlling the development of the market of logistics services, the orientation of the subjects of management of logistics flows and processes to achieve the goals of the national logistics system development, provided for by the National Logistics Strategy, implementation of the strategic action plan. This plan provides for the implementation of na- tional and regional infrastructure projects, as well as local strategies for the development of logistics service providers, determine the boundaries, size and maturity of the logistics market.

It should be noted that the allocated functions and controlling LSM operations of demonstrate a fundamentally new way of realizing the concept of public-private partnership, according to which the state should be interested in the effective development of the logistics infrastructure and the market of logistics services. At the same time, it is the state that determines the strategic and socially necessary and significant goals of national importance for logistics service providers and their clients. Business has the right to commercial use of state property on the conditions of concession relations and state leasing of objects of logistics infrastructure.

The mechanism of controlling the logistics services market has a special character:

- its strategic focus on the development of a system logistics provider, the involvement of enterprises of various industries in the formation of integration forms of logistics entities, the organization and management of targeted use of budgetary and extra-budgetary funds for the implementation of the National Logistics Strategy;

- the goal is conversion of the intersectoral goals of logistics activities, optimize financial, intellectual and labor resources to achieve strategic goals at the lowest cost, timely identify strategic gaps and make changes in strategic and operational plans;

- the result of controlling the predictions, assessments and redistribution of systemic and non-systemic risks of the implementation of innovative projects in the context of public-private partnership of business and government with subsequent adjustment of their budgets.

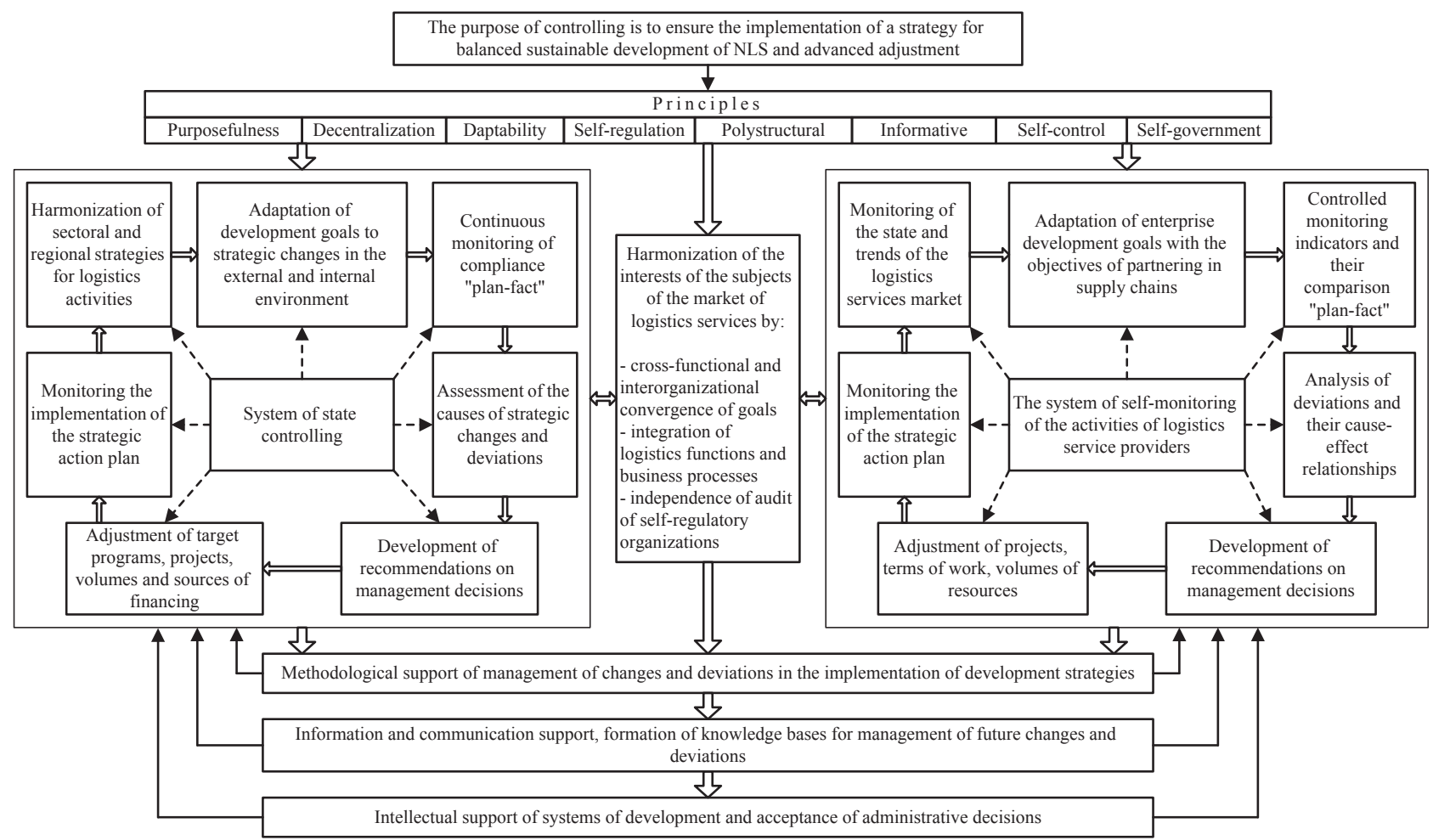

Fig. 3. Structural scheme of interaction of mechanisms of state regulation and self-regulation in the system of controlling the logistics services market 
The state policy in the field of logistics and transport actually determines the global function of LSM controlling, the purpose of which is ensuring compliance with the priorities of the National Logistics Strategy, international requirements, STP achievements, investment conditions and the like. However, the subjects of state power (the Ministry of Infrastructure of Ukraine, the Ministry of Economic Development and Trade, the Antimonopoly Committee, the State Statistical Service, the State Audit Service, the State Property Fund and others) by their nature do not have the capacity to provide a qualitative financial and economic study on certain problems of development of the logistics market services on a macroeconomic scale.

To implement controlling at different levels of management of the development of the logistics services market, the choice of a system of indicators is important. In the scientific and business literature there are various systems of indicators that characterize the activities of business entities and the state of national and regional economic systems. The most modern in terms of complexity of research and development is a balanced scorecard (BSC, Balanced Score Card) [21, 23]. The main advantage of a balanced system of indicators is that this system allows you to create a database not only about the financial side of the organization and its structural units, but also about the qualitative by means of decomposition of indicators. It is an innovative scheme that, while preserving the main financial parameters, including indicators of the strategic development of the organization in the scope of the research, as well as estimated indicators of its financial condition in the future, taking into account the prospects.
Fig. 4 presents the structure of the conceptual modules for the BSC formation for the purposes of monitoring logistic activities at different levels of management. It provides an opportunity for operational control of internal units and the organization as a whole, analysis of deviations and implementation of corrective actions to achieve strategic objectives of logistics and indirectly the goals of the national economy. Developed and approved in logistic companies, indicators should become the object of information aggregation and coordination for the BSC development at the macro level. To ensure inter-level interconnection of indicators, it is necessary to determine indicators on a bottom-up basis. Thus, a multilevel system of balanced indicators of logistic activity by management levels requires specification of specific strategic goals and indicators of their achievement, periodicity of control and degree of detail, automation of control facilities and tools, data collection and reporting systems. The effectiveness of the application of key performance indicators in logistics is largely determined by the correctly constructed corporate database on logistics operations and processes.

To evaluate the effectiveness and efficiency of the activities of market players in logistics services in implementing the chosen strategy, the desired (ideally) values of local indicators of the efficiency of logistic activity for each key competence must first be calculated. They are determined taking into account the expectations and wishes of customers and other stakeholders, projected market changes, factors of the internal and external environment, and also based on the best actual values of these indicators for previous periods.
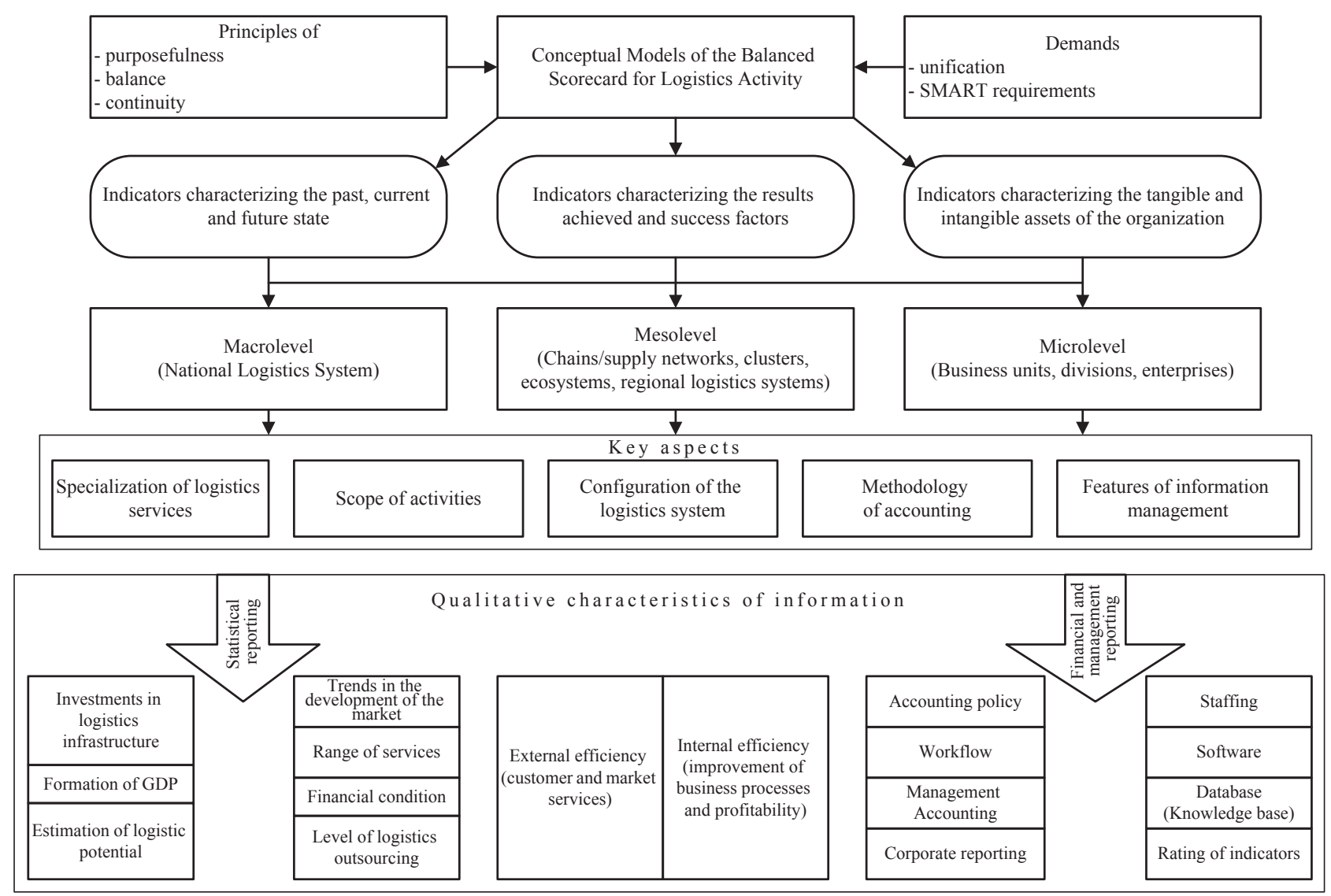

Fig. 4. Structural diagram of the conceptual modules of the balanced scorecard system of the activity of the subjects of the market of logistics services 
On the basis of these indicators, the desired (benchmark) values of integrated indicators of the efficiency of logistics activities are determined. Comparison of the actual integral indicator of the efficiency of logistics activities with the desired reflects the degree of implementation of the market strategy of logistics service providers allows to assess the existing deviations.

One of the most important problems of effective controlling of the logistics services market is the definition of expected zones for the emergence of strategic gaps in order to have a time reserve for making strategic decisions and to minimize the negative consequences of the gap to its transition to strategic drift and the escalation of the problem situation into a crisis one. To do this, as a rule, use the methods of functional and cost analysis, methods of risk assessment and prevention, a scenario method and a balanced scorecard for both individual logistics companies and for diagnostics of supply chains/networks.

Thus, the system of controlling the logistics services market is concretized by balanced indicators of the effectiveness and efficiency of logistics activities at different levels of management. It transforms the strategic goals of the organizations (market entities) into a clear operational plan. At the same time, it makes it possible to assess the performance of the company in terms of implementing the chosen development strategy with the help of key performance indicators. Being elected as a tool for managing and implementing the organization's strategic goals, a balanced scorecard system gives many preferences, namely:

- allows to concentrate management efforts on strategically important goals of micro, meso and macro levels of logistics activities;

- to understand the effectiveness and transparency of the actions of each link in the commodity movement; - to carry out control and controllability of logistical processes in horizontal and vertical foreshortenings.

\section{SWOT analysis of research results}

Strengths. The strength of the study is the methodological basis for combining forms, methods and mechanisms of state regulation and self-regulation of the logistics services market. This allows to build a hierarchy of management of logistics systems of micro-, meso- and macrolevels. The proposed system of controlling the state and trajectory of the strategic development of the logistics services market, which allows to harmonize the economic interests of the state and market entities.

Weaknesses. The weak side is that the implementation of the proposed mechanisms requires a thorough restructuring of the system of collecting and accumulating information on the state and dynamics of the logistics market. It is also necessary to change the system of statistical indicators and develop new approaches to their analysis and forecasting of future market conditions.

Opportunities. Opportunities for further research are the specification of indicators of logistics activities at each level of the hierarchy of management of the market of logistics services. Also requires further research activities of self-regulatory organizations in the field of logistics and transport (associations and professional associations).

Threats. Threats to the results of the carried out studies are that the logistics services market is constantly changing, new management and information and communication technologies are emerging, changing the relationship between the state and business. There are growing demands for sustainable development of the national economy, which requires more stringent state regulation. On the other hand, self-regulation of the logistics market contributes to its innovative development and active implementation of new business models of logistics activities. All this makes it necessary to change the socio-economic institutions and forms and methods of optimal combination of state and self-regulation of logistics activities.

\section{Conclusions}

1. The theoretical basis, forms and methods of state regulation of development of logistics in Ukraine are substantiated. Three components are distinguished:

- mechanism of state regulation of logistics activities at the macro level;

- mechanism of market self-regulation, determines the activities of logistics service providers at the micro level;

- mechanism of interaction, harmonization of interests and social partnership, realizes the management of logistical flows at the meso level by creating new integration forms and logistic entities on regional or sectoral grounds.

The attention is focused on the fact that the state should stimulate, on the one hand, the efficiency and innovativeness of the subjects of the market of logistics services, and on the other - strictly control compliance with regulatory and legal acts and standards of quality of logistics services and environmental requirements. State management of logistic flow processes in supply chains/networks, clusters and other organizational forms will help to reduce the total added value in the structure of the national gross product and help to increase the efficiency and competitiveness of the national economy.

2. Prospective directions and forms of self-regulation of the market of logistical services are defined in the context of state priorities. The growing role of self-regulating organizations (associations, professional associations, unions) in the formation of professional standards, codes of fair competition, increasing the level of competence of the subjects of logistics activities is proved. The conclusion is made about the need to develop hybrid forms and introduction of the principles of public-private partnership.

3. A system of logistic controlling has been developed to timely adjust strategic goals and introduce changes in the development of the logistics services market. The conceptual model of controlling the market of logistics services is developed, which includes modules of state control and self-control of market subjects. A system of balanced indicators of the efficiency of logistics activities is proposed, which will allow the collection and processing of statistical data.

\section{References}

1. Hontsiiazh Ya. Derzhavne upravlinnia v konteksti yevropeisko intehratsii. Kyiv: HO «Laboratoriia zakonodavchykh initsiatyv», 2015. 28 p

2. Connecting to Compete: Trade Logistics in the Global Economy / Arvis J.-F. et al. The International Bank for Reconstruction and Development/The World Bank, 2016. 82 p. 
3. The Logistics report 2016. Delivering safe, efficient, sustainable logistics // Freight Transport. 2016. URL: http://www. $\mathrm{fta}$.co.uk/export/sites/fta/galleries/downloads/logistics_report/ lr16-web-030616.pdf

4. Fact-finding studies in support of the development of an EU strategy for freight transport logistics. Lot 1: Analysis of the EU logistics sector Ecorys. URL: https://ec.europa.eu/transport/sites/transport/files/themes/strategies/studies/doc/201501-freight-logistics-lot1-logistics-sector.pdf

5. Porter M. Konkurentnaya strategiva: Metodika analiza otrasley i konkurentov. Moscow: Alpina Biznes Buks, 2005. 454 p.

6. Ihnatiuk A. I. Haluzevi rynky: teoriia, praktyka, napriamy rehuliuvannia: monograph. Kyiv: NNTs IAE, 2010. 110 p.

7. Roy L., Tretyak V. Analiz otraslevykh rynkov: handbook. Moscow: Business \& Economics, 2017. 387 p.

8. Sorkin B. V. Derzhavne rehuliuvannia pidpryiemnytskoi diialnosti v rynkovykh umovakh: metody, zasoby ta tsili // Naukovi pratsi MAUP. 2013. Vol. 1 (36). P. 85-88.

9. Isakov M. H. Rol derzhavy v rehuliuvanni pidpryiemnytskoi diialnosti $\mathrm{v}$ umovakh rynkovoi ekonomiky // Mytna sprava. 2012. Vol. 1 (79). P. 354-360.

10. Sadlovska I. P. Rozvytok natsionalnoi transportnoi merezhi Ukrainy ta yii intehratsiia do priorytetnykh transportnykh merezh YeS // Zbirnyk naukovykh prats Derzhavnoho ekonomiko-tekhnolohichnoho universytetu transportu. 2015. Vol. 31. P. $16-26$.

11. Dashkuiev M. A. Suchasnyi stan protsesu intehratsii transportnolohistychnoi systemy Ukrainy v yevropeiskyi subrehionalnyi prostir // Biznes Inform. 2015. No. 5. P. 133-140.

12. Dykan V. V. Formuvannia stratehii derzhavnoho rehuliuvannia stvorennia ta funktsionuvannia promyslovo-lohistychnoi systemy // Visnyk ekonomiky transportu i promyslovosti. 2014. Vol. 47. P. 15-19.

13. Dubinina M. N. Stitutional provider of the state-private partnership in Ukraine and abroad // Modern Economics. 2018. No. 7 P. 68-76. URL: https://modecon.mnau.edu.ua/issue/7-2018/ UKR/dubinina.pdf

14. Maksimov V. V. Gosudarstvenno-chastnoe partnerstvo v transportnoy infrastrukture: kriterii otsenki kontsessionnykh konkursov. Moscow: Apina Pablisherz, 2010. 178 p.
15. Honcharenko O. Samorehuliuvannia ta spivrehuliuvannia hospodarskoi diialnosti // Pidpryiemnytstvo, hospodarstvo i pravo. 2017. No. 9. P. 62-66.

16. Evangelista P., Colicchia C., Creazza A. Is environmental sustainability a strategic priority for logistics service providers? // Journal of Environmental Management. 2017. Vol. 198. P. 353-362. doi:10.1016/j.jenvman.2017.04.096

17. Boeva B. Corporate Governance and Global Supply Chains: How Self-regulation Replaces the Lack of Regulatory Initiatives or Do Regulatory Initiatives Add Value to Corporate Governance // Economic Alternative. 2015. No. 4. P. 5-19.

18. Watanuki M. Review of Logistics Service Regulations for Freight Forwarding Businesses: What Should Be Addressed for a Better Logistics Regulatory Framework? // World Bank Policy Research Working Paper No. 7401. 2015. doi:10.1596/18139450-7401

19. Baldwin R., Cave M., Lodge M. Understanding Regulation: Theory, Strategy, and Practice. Oxford: Oxford University Press, 2011. 568 p. doi:10.1093/acprof:osobl/9780199576081.001.0001

20. Arefieva O. V., Diakon L. L. Mekhanizmy kontrolinhu biznesprotsesiv promyslovykh pidpryiemstv: monograph. Kyiv: European University, 2008. 92 p.

21. Kulyk V. A., Popov V. I. Stratehichnyi kontrolinh innovatsiinoho rozvytku aviapidpryiemstv: monograph. Kyiv: NAU, 2010. 164 p.

22. Odintsova T. Kontrolinh u zabezpechenni zbalansovanoho staloho rozvytku pidpryiemstv i perspektyvy yoho rozvytku v Ukraini // Visnyk TNEU. 2013. Vol. 1. P. 165-174.

23. Sergeev V. I. Novoe videnie sistemy kontrollinga logisticheskikh biznes-protsessov $\mathrm{v}$ tsepi postavok // Logistika i upravlenie tsepyami postavok. 2007. No. 5. P. 9-22.

24. Hryhoriev H. S. Kontseptsiia derzhavnoho kontrolinhu v systemi rehuliuvannia finansovo-ekonomichnykh protsesiv natsionalnoi ekonomiky // Ekonomika: realii chasu. 2016. No. 3 (25). P. $187-196$

Grygorak Mariya, PhD, Associate Professor, Head of the Department of Logistics, National Aviation University, Kyiv, Ukraine, e-mail: m grigorak@ukr.net, ORCID: https://orcid.org/0000-00025023-8602 